\title{
COVID-19 Disrupts U.S. Higher Education Industry Reimagining the Future
}

\author{
Prema Nakra \\ Marist College
}

As people and businesses around the world enter the new year, businesses, economists, policy makers and risk management specialists begin to develop a list of existing and new sources of global risks. Ringing in "Year 2020" was no different. But the possibility that, COVID-19 would turn into global pandemic did not make the list. The World Health Organization (WHO) labeled the new virus a pandemic in the beginning of year 2020. China recognized this highly contagious and dangerous virus in December 2019. As we welcomed year 2020, the coronavirus crisis (COVID-19) began to upend the economies, industries as well as the lives of people around the world. Using secondary research sources, I will present the challenges that HEI will face in years to come in the aftermath of COVID-19.

Keywords: governance, endowments, revenue model, administrative bloat, global student mobility

\section{HIGHER EDUCATION INDUSTRY: A BRIEF OVERVIEW}

Higher education, also called post-secondary education, third-level or tertiary education, is an optional final stage of formal education that the students pursue after completing their secondary education. Degree granting colleges and universities are referred to post-secondary institutions that are eligible for Title IV federal financial aid programs and that grant an associate or higher degree. In other words, the higher education industry sector comprises all universities, colleges and other institutions providing formal tertiary education programs, according to the National Center for Education Statistics (NCES,2020).

The United States retains most of the world's top educational institutions, especially at the highest levels. 7 of the top 10 and 22 of the top 50 ranked higher education institutions are in the United States. Research conducted at U.S. institutions is cited more than that done in any other region of the world. The U.S. share of Nobel laureates in physics, chemistry, medicine, and economics has risen over the last 20 years (Quintana, 2013). The country's higher education system is decentralized and diverse, with each institution having the autonomy to determine its own program requirements guided by the states or specialized accrediting agencies. (ACE, 2019; MIT, 2020). The decentralized nature of U.S. higher education also allows for considerable variance in study abroad participation from institution to institution and from state to state.

\section{Industry Governance}

The U.S. higher education enterprises comprise of approximately 4360 degree granting institutions and more than 21.9 million students. Unlike most countries, the US-has no ministry of education or other central agency with overall responsibility for higher education nationwide. The American Council of Education 
(ACE) serves as the major higher education coordinating organization in the U.S. Responsibility for accreditations of academic programs and education institutions is assigned to private non-governmental organizations. These accrediting agencies or bodies are retailed by the U.S. Department of Education, or other funding sources. (ACE report 2019)

The U.S. Federal government creates oversight policies, provides funding, regulates and administers student and other loans to individual students, institutions and states. As reported by American Association for the Advancement of Science (AAAS), the federal government also funds a majority of university research and development. To be eligible for receiving federal funds these accrediting agencies must be certified by the U.S. Department of Education. Key organizations responsible for formalizing the HEI include: The National Center for Education Statistics (NCES) and the Carnegie Classification of Higher Education (ACE, 2019).

Public colleges and universities are governed by the states. The degree of control over the operations of colleges and universities varies from state to state. State and local governments normally provide direct operating support to public colleges and universities, based on their operating revenues. Currently, direct support provided by state and local governments to private colleges and universities is approximately 2 percent or less of institutional revenues. Institutes of higher education are classified as public institutions and private institutions. Private institutions are also classified as Private for-profit and Private not-for-profit institutions (MIT, 2019)

\section{Revenue Model}

Much of the higher education sector uses an unconventional revenue model. The price (tuition) that these institutions charge for their core service(s) only partially covers the costs of providing this operation. As reported by McKinsey (2020) tuition and fees make up 26 percent of revenues for four-year public institutions and 35 percent for four-year private non-profit institutions. Critical sources of revenues for U.S. colleges and universities include but are not limited to private donations originating from alumni, nonalumni individuals, foundations, corporations, other organizations, and religious entities (Baum, et. Al.).

\section{Role of Endowments}

A college endowment refers to all the money that an institution receives in donations. These donations are held in tightly controlled investments. Interest earned from the investment of endowed funds is used to upgrade facilities, develop state of the art technology infrastructure and research facilities, hire new staff, provide scholarships or aid the college or its students. Larger endowments also enable institutions to reduce tuition costs and/or grant more financial aid and scholarships. According to the report by the financial services organization TIAA and the National Association of Colleges and University Business Officers report, in 2019 alone, Endowments contributed about $\$ 23$ billion to university budgets. This amounts to \$31 million per campus (Quintana, 2020).

\section{Fee Structure}

Overall, the US higher education system is a high-cost, high-aid system with financial aid structures that are extensive and complicated. Public universities generally charge lower tuition than private ones. Out-of-state students are often required to pay higher tuition because their families have not paid state taxes that underwrite the cost of a public post-secondary education. Some universities offset budget cuts by aggressively recruiting foreign and out-of-state students, who pay much higher tuition rates.

College students are potentially eligible for federal, state or institutional aid. Institutional aid is financial assistance provided by the college and varies by school, since each college uses its own policies and formulas to determine how to award its financial aid.

Approximately 85 percent of potential students, planning to enroll in colleges, file the Free Application for Federal Student Aid (FAFSA). This application is used by many state agencies and colleges and universities to determine each prospective student's eligibility for grants and federal loans. 


\section{Globally Mobile Students}

In 2019, the total number of international students enrolled in US colleges was 1,075, 496, making up $5.5 \%$ of the total student body. Of this total 431,930 were undergraduate students, 377,943 were graduate students, and 62,341 were enrolled in non-degree programs. Number of workers Optional Practical Training (OTP) was 223,085. (Nafsa.org, 2020). International students tend to pay full price, thus effectively subsidizing American students.

\section{HIGHER EDUCATION INDUSTRY: PRE-COVID-19}

Higher education industry was ripe for a remake long before the onset of COVID-19. For past ten years, higher education has faced environmental issues including but not limited to increased global competition, burgeoning student and institutional debt and growing compliance costs. The onset of COVID-19 created additional challenges while accelerating the impact of external demographic, financial, technological and political trends on this industry sector (Lundy, 2020).

\section{Financial Challenges}

The industry has been in serious financial trouble for the past two decades. It was threatened by financial strain, due to rising labor costs, falling public funding, suppressed tuition revenues, and democratic challenges of declining college age population as reflected in downturn in the nation's birthrate, as well as growing skepticism about the price and value of a college degree. Industry leaders have been grappling with the issues relating to the decline in financial support, mental health, diversity and inclusion, and affordability for many years.

\section{Demographic Deficit}

Economists have warned about the coming demographic deficit. It was projected that by 2026 , the number of traditional college age students will fall sharply and quickly. In other words, the number of highschool graduates in the United States will peak at around 3.6 million students in 2026 and then decline to 3.3 million students by 2030. (NCHS, 2020). Since student revenues represent the largest source of general funds dollars, this demographic deficit raised the prospect that fewer young people will move through the educational system even if COVID-19 did not happen (NCHS, 2020; Douglass, 2020).

\section{International Students}

Long before COVID-19 disrupted higher education and international student mobility, there were clear signs that the United States' enrollment of international students was in decline. A survey conducted in 2017 by Royall \& Company reported that one-third of prospective international students were less interested in studying in the United States because of the political climate. and 74 percent of surveyed admission directors agreed that U.S. travel ban and negative immigration policies had made it more difficult to recruit international students (Dennis, 2020). Since 2016, globally mobile students, especially those from India and China opted to enroll in universities in Canada or Australia. These countries not only offered higher education at world class universities but they offered the students opportunities to work in their respective countries after completing their higher education.

In summary, at the start of 2020, higher education institutions were bracing for a challenging decade. On the horizon were double-digit demographic swings, a looming economic downturn, steadily increasing demand for online education, shifting student and parent expectations, ever-changing technology and more. Then came the COVID-19 outbreak. Industry leaders are concerned that the COVID-19 crisis could further accelerate this decline (Dua, et. Al, 2020; Fry, 2020).

\section{SHAPE OF THINGS TO COME}

Year 2020 started with a high sense of economic optimism in the United States and in many countries across the globe. In the United States the job market was the strongest in fifty years. Demand for a talented 
workforce was growing across multiple global industries. And then came COVID-19 as a global pandemic. COVID-19 brought travel to a halt globally, it shut down business and schools.

In very few places are the effects of COVID-19 more visible than on the higher education campuses, which now sit largely devoid of students, staff and faculty. Classrooms as well as athletics facilities are all empty. Dormitories have shuttered, while study abroad and other academic programs are on hold. Most colleges moved classes online, canceled spring sports, and instructed students to vacate their dorm rooms. At the end of March 2020, at least 1102 colleges and universities have temporarily closed and moved to a digital platform, impacting over 14 million students (Hess, 2020). As the campuses were deserted, information technology became center stage to solidify its place in the higher education industry as a key collaborator to allow faculty members and students to complete the spring 2020 semester.

\section{Financial Impact of COVID-19}

With campus closures, many institutions' student support services funded by auxiliary fees were been significantly reduced. Colleges began to take heavy hits as they refund money to students for housing, dining and parking after campuses closed in March 2020. Many schools began to lose millions in ticket sales after athletic seasons were cut short. Operating costs skyrocketed, given decreased dorm and dining hall density and higher cleaning, information technology and health services costs.

As per Moody's projections, approximately. 87 percent of small private colleges and 74 percent of medium sized private universities will see decline in net tuition revenues in fiscal 2021. Sixty-four percent of comprehensive private universities will also see decline in net tuition revenues in fiscal 2021. Due to financial distress the industry will see increase in merger and acquisition activities whereby, smaller colleges will merge with larger ones (Whitford, 2020; TIAA, 2020)

As enrollment continues to decline, the higher education industry will see a bifurcation in the higher education sector. For institutions that were already financially stressed or operating from a deficit position prior to the pandemic, short-term unanticipated expenses and longer-term enrollment declines threaten their solvency, and potentially lead to closures, mergers or acquisitions (Lundy, 2020: Vedder, 2020). Those with strong reputational capital will face uncertainty but will ultimately emerge strong contenders in the higher education industry.

\section{Student Enrollment Impacts Revenues}

Thousands of students across the country are rethinking their Fall 2020 college decision or wondering whether they will be able to go to college in Fall 2020 or beyond. Students from families feeling uncertainty about the economy with more than 40 million people applying for unemployment benefits by the end of May 2020, were considering a gap year (Whistle, 2020). Case in Point: FAFSA serves as the way to secure federal grants and loans, financial aid from states as well as individual colleges. By December 2020, the number of high school seniors nationally who had filed the Free Application for Federal Student Aid (FAFSA) was down about 14 percent from the same time in 2019 (NCAN, 2020, Lorin, 2020).

The 2019-2020 admission cycle saw record numbers of deferrals from accepted students who opted to take a year off rather than to college online in Fall 2020. New students who had completed their high school education were also considering whether to delay their college education by one year. Even with a COVID19 vaccine available many students will still opt to take a gap year during Spring 2021 (Carrns, 2020; Quintana, 2020).

\section{Globally Mobile Students}

Colleges across the country took huge hits in international students during the 2020-2021 school year due to travel restrictions caused by COVID-19. Enrollment of new international students fell $43 \%$ in 2020 , with overall international enrollment at US universities fell by 16 percent in Fall 2020. A survey conducted by the Institute of International Education (IIE) in May 2020, concluded that international higher education exchange will result in reduced number of in-bound and out-bound students. Colleges and universities that have established partnerships and strategic alliances with universities in other countries will also be unable to take full advantage of these collaborations (IIE, May 4, 2020; Baer et. Al 2020). 


\section{State Funding and Federal Relief}

Since the onset of COVID-19, States have been scrambling to deal with rising healthcare costs while receiving lower tax revenues due to closure of businesses. The Urban Institute (2020) estimates that state revenues will fall by as much as $\$ 200$ billion by end of the 2021 fiscal year. Consequently, higher education appropriations by states will be cut to offset declining tax revenues (Whitford, 2020).

In April 2020, Congress passed the CARES Act to provide relief from the coronavirus. Approximately $\$ 14$ billion, was allocated to higher education. For many colleges the amount allocated would not be enough to cover the costs of technology, and housing refunds. In December 2020, The Department of Education authorized a \$21.2 billion COVID-19 relief to higher education institutions. The amount, however, is significantly less than the $\$ 120$ billion request made by associations representing U.S. colleges and universities. (Whistle, 2020; Murakami, 2021).

\section{FUTURISTS' VIEW: STRATEGIC TRANSFORMATION}

Colleges and universities have a long history of dealing with disruptive economic and political environments. The pandemic has given them a pause to reflect and reimagine the future of the higher education industry. As the COVID-19 emergency subsides a new world order will emerge with unique challenges and opportunities. Industry leaders will have an opportunity to be involved in a thoughtful, strategic transformation of higher education. The path forward will be different for each institution, depending on their respective core mission and value proposition. Multiple strategic initiatives have been identified for consideration by higher education industry participants.

\section{Reevaluate Strategic Plans}

Most higher education institutions develop comprehensive strategic planning initiatives every three or five years. Innovative leaders will holistically and thoroughly reevaluate their plans to position their respective organizations to succeed in the emerging environment. To proactively manage their financial resources, institutions will also review their academic programs and modify or eliminate the programs that are nonessential to their core mission. Degree programs and courses involving data-analytics, for example, will gain newfound importance as the employers in multiple industries are seeking employees that possess those skills.

Moody's Investors Service announced in August 2020 that hybrid, non-degree programs are growing at a rapid rate. Opportunities to offer certificate and digital pathway programs, vocational programs with technical skill-set are likely to grow. Colleges and universities will find opportunities to offer these technological skill-based programs by collaborating with private corporations. Some of the front runners in offering skill-based training and certificate programs include Coursera, Bloomberg Philanthropies, IBM, Facebook, Google and Microsoft. Their certificate programs are being offered independently or in collaboration with the colleges and universities, in public and private not-for-profit sectors.

\section{Information Technology Takes Center Stage}

Artificial intelligence (AI) and machine learning (ML) have been adopted in most industry sectors, and higher education is no exception. Colleges and universities will continue to redesign their academic programs and enhance student learning experiences. Robotic process automation is also gaining acceptance by innovative leaders in higher education (Brownlee, 2020; Duncan and Lundy, 2020).

\section{Operational Efficiencies}

As colleges and universities grapple to deal with their respective financial issues, they have implemented short term steps ranging from faculty and staff hiring freezes, pay cuts, furloughs or lay-offs of term and adjunct faculty members, deferral of sabbaticals for faculty members among others. These tactics will not put a dent in the cost structure of institutions that are implementing them. Going forward, it is important to seriously engage in cost-benefit analysis before these measures are taken. Case in Point: In 
the past forty years, the growth rate in the number of administrative staff in colleges and universities has been rising leading to "administrative bloat".

Additionally, as COVID-19 spreads, critical minds are also seriously questioning the logic of sevenfigure salaries of football coaches and assistant coaches in the current economic environment. Case in point: At the end of year 2019 Entertainment and Sports Programming Network (ESPN) disclosed the salaries of Head caches of NCAA athletic programs. Comparing the salaries of the head coaches of NCAA athletic programs, ESPN reported that they were the highest paid employees in 40 of the 50 States of United States. As disclosed by John Duffley (2019), the salaries of 37 head coaches hired by the State Universities ranged between $\$ 1$ million and \$9.3 million. Nine of these head coaches earned more than $\$ 6$ million each.

Institutional leadership will grapple to find ways to reduce the administrative bloat and facilitate renegotiation of the benefit packages offered to football coaches and assistant coaches. (Pilon, 2020; Randall, 2020). Moving beyond year 2020, higher education industry leaders must think about how to allocate scarce resources. College boards are expected to aggressively review administrative/ instructional cost ratios and administrative/student enrollment ratios as measure of their respective institutions' financial performance.

\section{Final Words}

The coronavirus pandemic has brought insurmountable grief and hardship for people and organizations around the globe, but it has also created unprecedented momentum for deep and structural change in societies and industries. Higher education industry is no exception. As illustrated in this article, higher education institutions are facing shrinking pools of both domestic and international students, driven by U.S. demographic trends, declining college enrollment rates as a result of the pandemic, and political uncertainty. It is time to critically scrutinize the patterns of spending and fiscal priorities of colleges and universities.

To sum up, higher education will continue to remain the cornerstone of our society. Its leadership must renew our commitment to the core values of academic freedom, institutional autonomy and engagement by students, faculty and staff. It is difficult to predict with certainty how the next chapter in the battle against COVID-19 will unfold or what its lasting legacy will be. However, the choices the industry leaders make today will redefine the face of the higher education industry for generations to come.

\section{REFERENCES}

American Council of Education (ACE). (2020, January). Ace Releases Handy Resource on Understanding U.S. Higher Education. Retrieved from https://www.acenet.edu/NewsRoom/Pages/ACE-Releases-Handy-Resource-on-Understanding-US-Higher-Education.aspx

Baer, J., \& Martel, M. (2020, November). Fall 2020 International Student Enrollment Snapshot. Institute of International Education (IIE). Retrieved from https://www.iie.org/en/Research-andInsights/Publications/Fall-2020-International-Student-Enrollment-Snapshot

Baum, S., Delbanco, A., \& Schapiro, M. (2018, March/April). The Business of Higher Education. AGB, 26(2). Retrieved from https://agb.org/trusteeship-article/the-business-of-higher-education/

Brownlee, M. (2020, August 6). After the Pandemic, Higher Education Can't Afford to Go Back to 'Normal. EdSurge. Retrieved from https://www.edsurge.com/news/2020-08-06-after-thepandemic-higher-education-can-t-afford-to-go-back-to-normal

Carrns, A. (2020, December 18). A Worrisome Drop in College Aid Applications. World News Era. Retrieved from www.worldnewsera.com

Deloitte. (2020). COVID-19's impact on higher education: Strategies for tackling the financial challenges facing colleges and universities. Retrieved from https://www2.deloitte.com/content/dam/Deloitte/us/Documents/public-sector/us-gps-covid-19impact-on-higher-education.pdf

Dennis, M. (2020, April 25). Covid-19 will speed up fall in international enrollment. University World News. Retrieved from https://www.universityworldnews.com/post.php?story=20200420115723916 
Dennis, M. (2020, March 28). How will higher education have changed after COVID-19? University World News. Retrieved from https://www.universityworldnews.com/post.php?story=2020032406563977

Dua, A., Law, J., Rounsaville, T., \& Viswanath, N. (2020). Reimagining higher education in the United States. McKinsey \& Company. Retrieved from https://www.mckinsey.com/

Duffley, J. (2019, December 31). In 40 States, Sports Coaches are the Highest-Paid Public Employees. Fan Buzz. Retrieved from https://fanbuzz.com/national/highest-paid-state-employees/

Duncan, B., \& Lundy, K. (2020, March 2). How universities are using robotic process automation. Ernst \& Young. Retrieved from https://www.ey.com/en_us/government-public-sector/how-universitiesare-using-robotic-process-automation)

Fitch Rating. (2020, December 8). Outlook Report: Fitch Ratings 2021 Outlook: U.S. Public Finance Colleges and Universities. Retrieved from www.fitchratings.com

Fry, J. (2020, September 30). 7 Ways COVID-19 is Accelerating Trends in Higher Education. Accenture. Retrieved from https://www.accenture.com/us-en/blogs/voices-public-service/7-ways-covid-19is-accelerating-trends-in-higher-education

Hess, A. (2020, March 23). How Coronavirus Dramatically changed college for over 14 million students. CNBC News. Retrieved from http://www.cnbc.com/2020/03/26/how-coronavirus-has-changedcollege-for-over-14-million-students.html

IIE. (2020). Institute of International Education. (2020b). Emergency Student Fund. Retrieved from https://www.iie.org/Programs/EmergencyStudent-Fund

Lesmerises, D. (2020, March 10). Ohio State Football Assistant Coaching Salaries are out of control. Cleveland.com. Retrieved from https://www.cleveland.com/osu/2020/03/ohio-state-footballassistant-coaching-salaries-are-out-of-control.html

Lorin, J. (2020, April 8). Colleges with Empty Campuses Face an Uncertain Financial Future. Bloomberg News. Retrieved from https://www.bloomberg.com/news/articles/2020-04-08/colleges-withempty-campuses-face-an-uncertain-financial-future

Lundy, K. (2020, October 23). How higher education institutions can evolve in a post COVID-19 world. Ernst \& Young. Retrieved from https://www.ey.com/en_us/education/how-higher-educationinstitutions-can-evolve-in-a-post-covid-19-world

MIT. (2020). Dynamics of the U.S. Higher Education Sector. Retrieved from http://forum.mit.edu/articles/dynamics-of-the-U-S-higher-education-sector/

Murakami, K. (2021, January 15). Billions in Aid head to colleges. Inside Higher Education. Retrieved from https://www.insidehighered.com/news/2021/01/15/education-department-releases-billionsaid-colleges

NAFCA. (2020). Trends in US Study abroad. Retrieved from https://www.nafsa.org/policy-andadvocacy/policy-resources/trends-us-study-abroad

NCAN. (2020, May 6). Steep Decline in FAFSA Renewals. National College Attainment Network. Retrieved from www.nscan.org

NCES. (2020). Integrated post-secondary education data system. National Center for Education Statistics, FY2018. Retrieved from www.nces.ed.gov

National Center for Health Statistics (NCHS). (2020). Births and General Fertility Rates: United States. Retrieved from https://data.cdc.gov/NCHS/NCHS-Births-andGeneral-Fertility-Rates-United$\mathrm{Sta} / \mathrm{e} 6 \mathrm{fc}-\mathrm{ccez} / \mathrm{data}$

Pilon, M. (2020, May 13). Can millionaire college coaches defend their salaries during Covid-19? The Guardian. Retrieved from https://www.theguardian.com/sport/2020/may/13/can-millionairecollege-coaches-defend-their-salaries-during-covid-19

Qunitana, C. (2020, April 14). Coronavirus could change where students go to college, if they go at all. USA TODAY. Retrieved from https://www.usatoday.com/story/news/education/2020/04/14/coronavirus-college-admissionsfafsa-financial-aid/2986961001/ 
Randall, D. (2020, April 17). Colleges Must Cut Administrative Costs to Survive This Crisis. Real Clear Education. Retrieved from

https://www.realcleareducation.com/articles/2020/04/17/colleges_must_cut_administrative_costs to_survive_this_crisis_110410.html

Redden, E. (2020, May 26). Colleges expect few new international students will make it their fall campus. Inside Higher Education. Retrieved from https://www.insidehighered.com/news/2020/05/26/colleges-expect-few-new-internationalstudents-will-make-it-their-campuses-fall

TIAA. (2020, September). The new normal: Higher education in a post COVID-19 world. Retrieved from https://www.tiaa.org/public/pdf/the-new-normal-higher-education-in-a-post-COVID-19world.pdf

Vedder, R. (2020, April 7). Why the Coronavirus Will Kill 500-1,000 Colleges. Forbes. Retrieved from https://www.forbes.com/sites/richardvedder/2020/04/07/500-1000-colleges-to-disappear-survivalof-the-fittest/\#63b8911811a1

Whistle, W. (2020, April 20). The Coming Financial Crisis for Colleges. Forbes. Retrieved from https://www.forbes.com/sites/wesleywhistle/2020/04/20/the-coming-financial-crisis-forcolleges/\#751f4eb54e68

Whitford, E. (2020, May 5). Public higher Education worse spot ever heading recession. Inside Higher Education. Retrieved from https://www.insidehighered.com/news/2020/05/05/public-highereducation-worse-spot-ever-heading-recession

Whitford, E. (2020, October 30). Colleges Forecast Net Tuition Revenue Declines for Fiscal 2021. Inside Higher Education. Retrieved from

https:/www.insidehihgered.com/quicktakes/2020/10/30/colleges-forecast-net-tuition-revenuedeclines-fiscal-2021 